\title{
О ПРОДУКТИВНОСТИ И ПЕТРОФИЗИЧЕСКИХ ХАРАКТЕРИСТИКАХ КОЛЛЕКТОРОВ СЕВЕРНОЙ ЧАСТИ БАКИНСКОГО АРХИПЕЛАГА
}

\author{
Мухтарова Х. З., Насибова Г. Д., \\ Азербайджанский Государственный Университет Нефти и Промышленности \\ Азербайджан, Баку
}

DOI: https://doi.org/10.31435/rsglobal_wos/30092019/6685

\section{ARTICLE INFO}

Received: 29 July 2019

Accepted: 25 September 2019

Published: 30 September 2019

\section{KEYWORDS}

deposits,

suit,

porosity,

deep,

well,

density,

petrophysics,

gorizont,

drilling,

geophysics,

oil and gas accumulatios.

\begin{abstract}
In the article was showed complex results of petro physical testing sample of rocks from taken digging prospecting-development wells which are widen productive unit sediments of the northern part of the Baku arxipelago. An average values of granulometric composition of rocks of productive unit the above areas by the section have been recount. The matter dependence of permeability from porosity and porosity from depth was solved.

The research showed that the same named and the same age rocks physical property change at the result of geological- physical process and getting different prices. The reservoir properties of rocks of productive unit have been learned. The physical properties of rocks of productive unit have been shown in the table. The reservoir properties of different type of rocks which take part in the geological structure of oil and gas bearing areas and their spreading conformity to natural laws are shown in the table.

Dependence between physical parameters for the individual kinds of rocks, dependence between physical properties and material structures are established.
\end{abstract}

Citation: Mukhtarova Kh. Z., Nasibova G. J. (2019) O Produktivnosti i Petrofizicheskih Harakteristikah Kollektorov Severnoj Chasti Bakinskogo Arhipelaga. International Academy Journal Web of Scholar. 9(39), Vol.1. doi: 10.31435/rsglobal_wos/30092019/6685

Copyright: (C) 2019 Mukhtarova Kh. Z., Nasibova G. J. This is an open-access article distributed under the terms of the Creative Commons Attribution License (CC BY). The use, distribution or reproduction in other forums is permitted, provided the original author(s) or licensor are credited and that the original publication in this journal is cited, in accordance with accepted academic practice. No use, distribution or reproduction is permitted which does not comply with these terms.

Введение. Уникальность ЮКБ и богатые углеводородные ресурсы издревле привлекали к себе внимание исследователей. Многочисленными наблюдениями было установлено, что углеводородный потенциал многих месторождений, особенно в глубокозалегающих горизонтах, ввиду отсутствия подробных данных о литофациальных и петрофизических свойствах коллекторов не был достаточно оценен. Ввиду этого, подробное изучение нефтегазоносных коллекторов продуктивной толщи в пределах возможностей современных петрофизических методов и данных ГИС остается весьма актуальным.

1. Тектоническое строение и стратиграфическая характеристика района исследования

В последние годы во многих регионах мира на глубине 3-6 км при температурном режиме $180-190{ }^{0} \mathrm{C}$ выявлены залежи, доказывающие возможность глубоко погруженных месторождений нефти и газа. Исследования также подтверждают предположение об образовании и накоплении УВ на глубинах более 6-7 км и высокотемпературных, т.е. 180-190 С зонах. Надо отметить, что еще во второй половине прошлого века по данным исследованиям предполагалось, что образование УВ и формирование залежей нефти и газа может происходить на любой глубине и при любой температуре. Так, например, Ю.М.Молчанов, Д.М.Хантом и др. было научно-теоретически обосновано существование и образование УВ на больших глубинах в режиме температур $350-400^{\circ} \mathrm{C}$ и давлений $100 \mathrm{MPa}$. 
Имеющий особенный интерес акватория Бакинского архипелага окаймляется глубоководной впадиной и составляет Юго-Восточную Гобустанскую складчатую зону, также включает Нижнекуринскую тектоническую депрессию, в которых сформировались многочисленные антиклинальные поднятия, которые по общим морфологическим и тектоническим характеристикам группируются в антиклинальных поясах и являются продолжением морской тектонической зоны.

Складчатость Дуванны-Хара-Зиря составляет северную антиклинальную линию Бакинского архипелага и располагающуюся в южной части Джейранкечмесской депресии. В межантиклинальных зонах располагаются локальные поднятия Булла-дениз, Умид, Ширвандениз и другие структуры [1].

Локальная структура Сангачал-дениз в тектоническом отношении представляет собой асимметричную куполовидную складку. Отделяется длинной, но неглубокой, седловиной от Кянизадагского поднятия. Юго-восточная периклиналь складки по отложениям ПТ отделяется неглубокой и короткой седловиной от поднятия Дуваны.

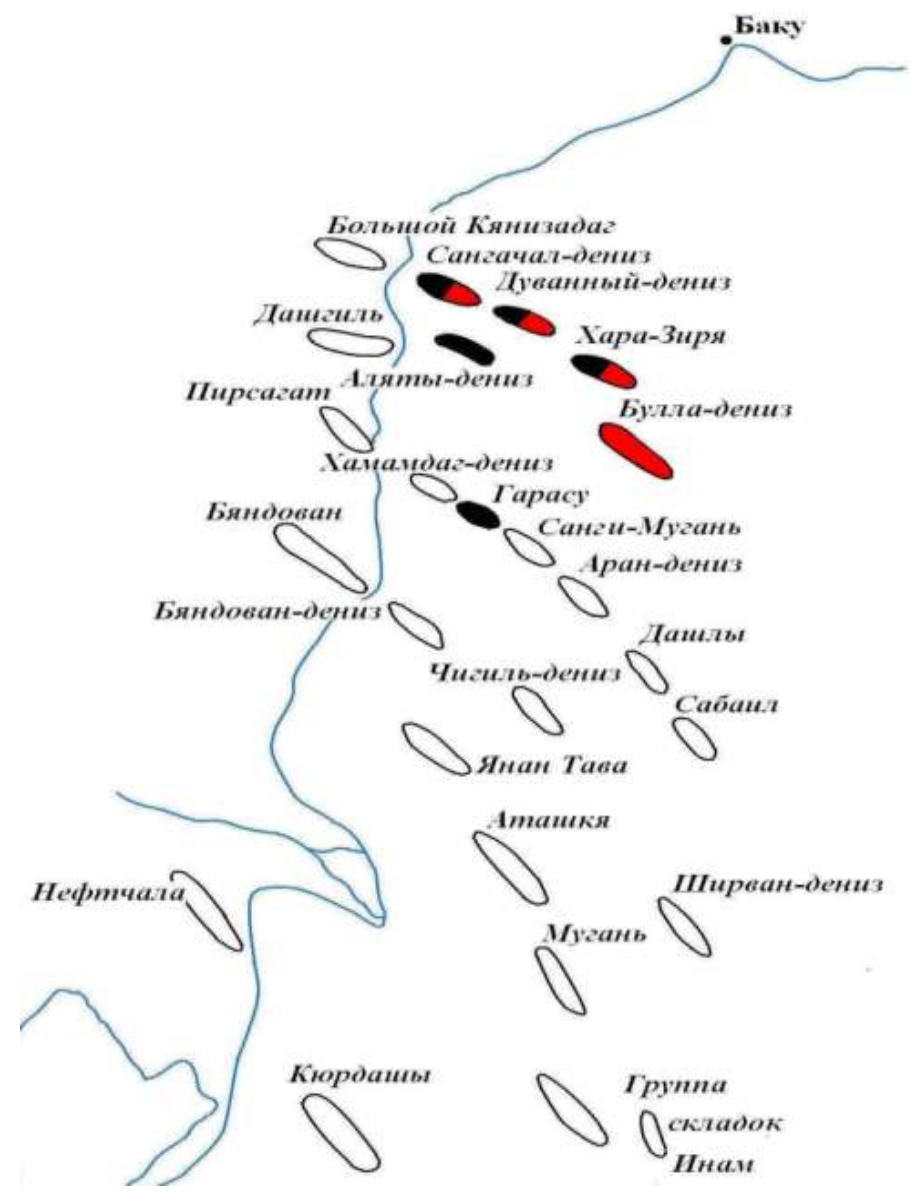

Рис.1. Нефтегазоносные структуры на севере Бакинского архипелага

По сводовой части структуры Сангачал-дениз проходит крупный продольный разрыв, пересекающий также площади Дуваны-дениз и Булла-дениз. На площади Сангачал-дениз разрыв взбросового типа с амплитудой 200-600 м (приподнято северо-восточное крыло), а на площади Дуваны-дениз - сбросового типа (опущено северо-восточное крыло) с амплитудой 500-1400 м. От продольного разрыва ответвляются два тектонических нарушения с амплитудой 30-150 м, дробящие общую структуру на три части: северо-восточное крыло, центральную часть и юго-западное крыло. Кроме того, по комплексным материалам выявлено еще 14 поперечных нарушений [1-3]. 


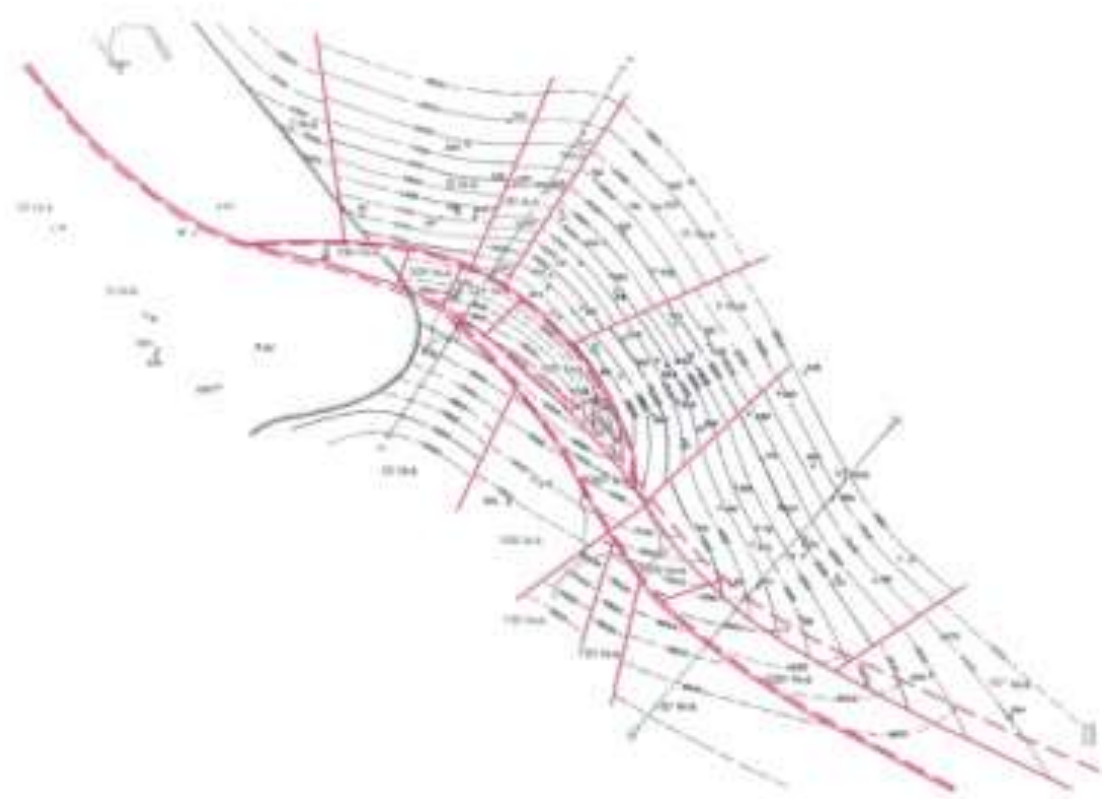

Рис.2. Структурная карта по кровле VIII горизонта месторождения Сангачал-дениз Дуванны-дениз

Нефтегазоконденсатные месторождения Сангачал-дениз и Дуванны-дениз располагаются последовательно в северной части Бакинского архипелага. В геологическом строении структур принимают участие отложения продуктивной толщи, акчагыльского, апшеронского ярусов и более молодые отложения вплоть до современных. ПТ обнажается в северной части поднятия, но в приосевой части она размыта на глубину до 750-800м. Стратиграфический разрез вскрытых пород представлен чередованием песков, песчаников и глин. Максимальная толщина отложений продуктивной толщи, соответственно пробуренным скважинам, составляет 3950-4000 м, а минимальная - 3000 м.

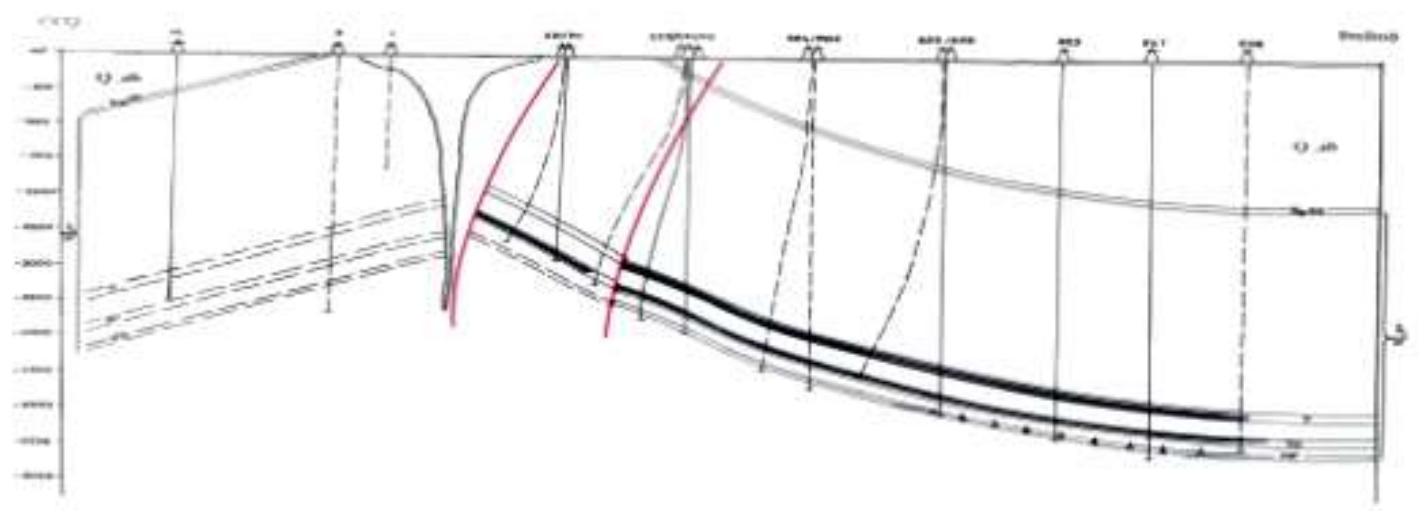

Рис.3. Геологический профиль месторождения Сангачал-дениз и Дуванны-дениз

Поднятие Булла-дениз расположено к юго-востоку от структуры Дуванны-дениз в северной части Бакинского архипелага. Строение поднятия изучено комплексно методами разведочной геофизики, картированием, структурно-поисковым и эксплуатационным бурением. Согласно этим материалам, структура Булла-дениз простирается с северо-запада к юго-востоку. Размеры структуры по кровле VII горизонта составляют $27 \mathrm{x} 9$ км, а высота достигает 1400 м. Структура представляет собой асимметричную брахиантиклинальную складку. Угол падения северо-восточного крыла $12-22^{0}$, а юго-западного $11-22^{0}[1]$. 


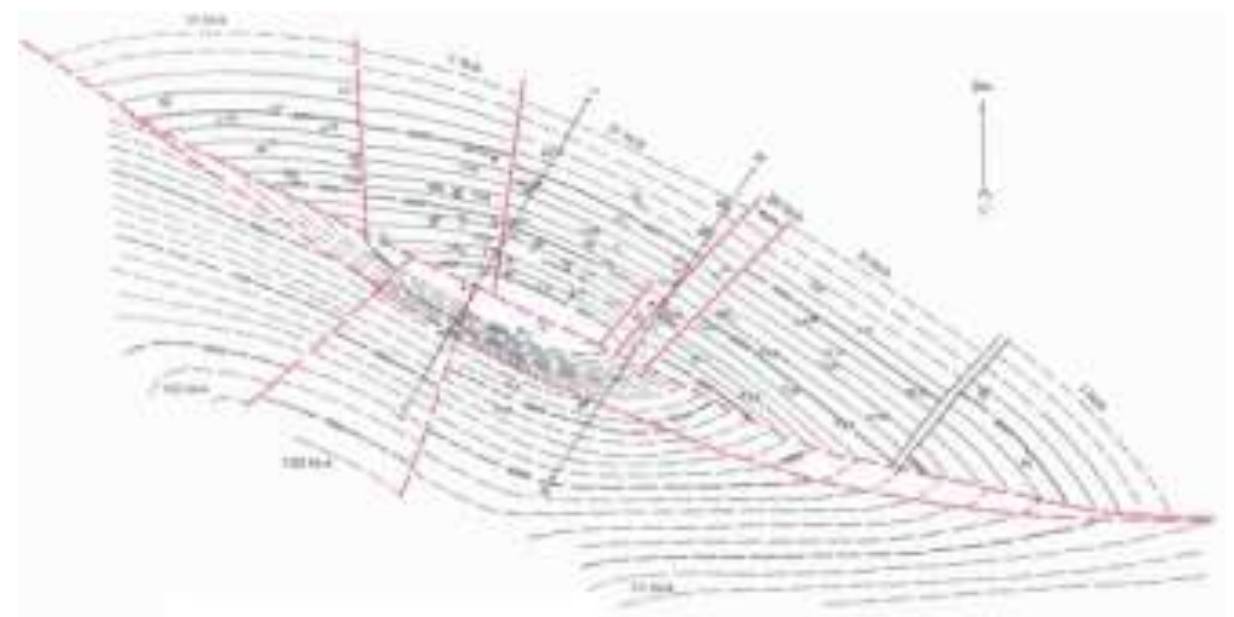

Рис.4. Структурная карта по кровле VII горизонта месторождения Булла-дениз

В геологическом строении площади участвуют отложения ПТ, акчагыльского, апшеронского ярусов и четвертичные образования. Отложения продуктивной толщи здесь вскрыты структурными и глубокими скважинами до верхней части кирмакинской свиты. Отложения ПТ, в основном представлены глинами, песчаниками и алевролитами.

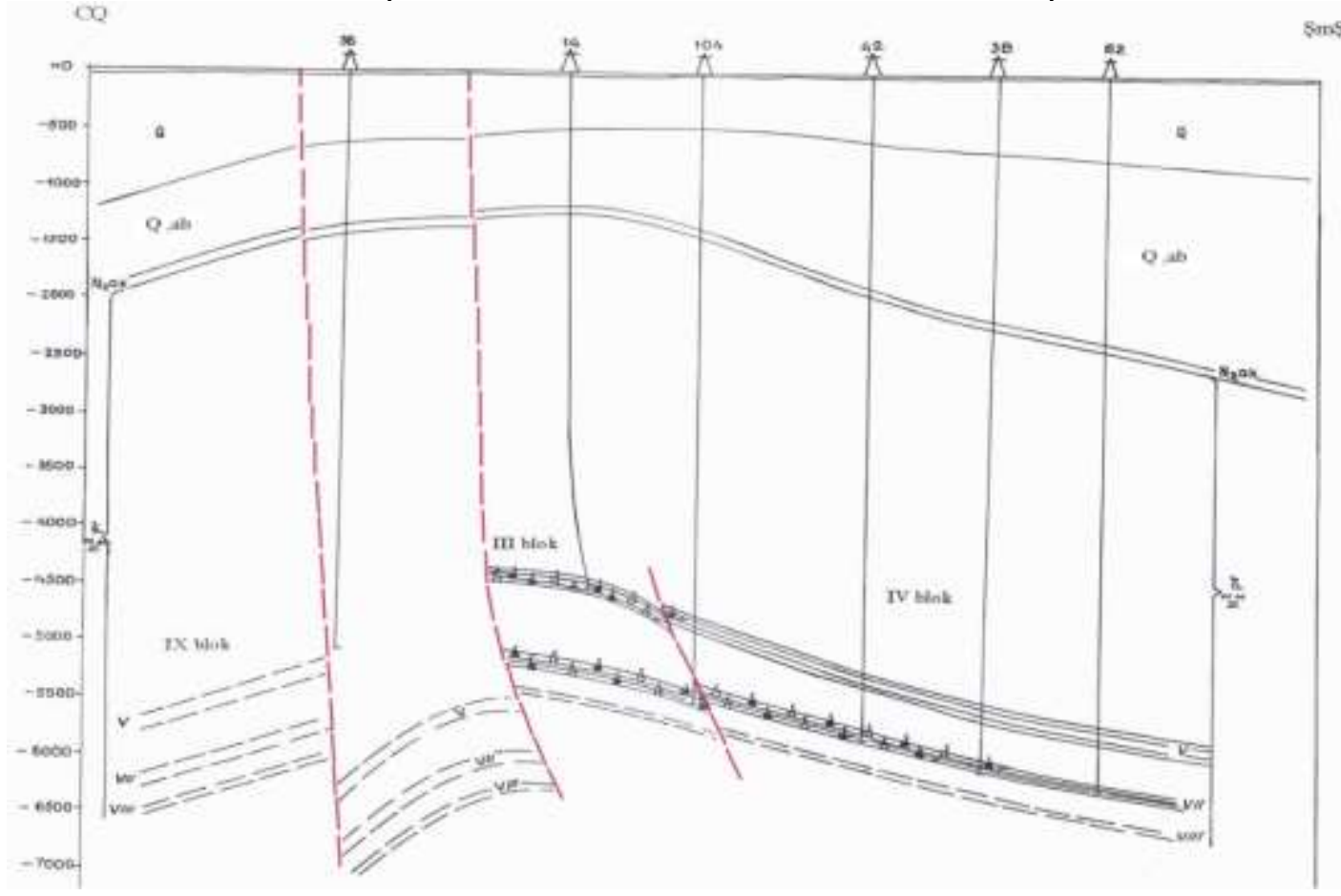

Рис.5. Геологический профиль Булла-дениз

Расположенное на юго-западе Бакинского архипелага, нефтяное месторождение Гарасу относится к наиболее изученным и охватывает территорию острова Гарасу и прилегающую акваторию. Поднятие Гарасу относится к антиклинальной зоне, протягивающейся с северозапада на юго-восток через поднятие Хамамдаг-дениз и далее в открытое море. Здесь отложения ПТ представлены в основном глинами, песчаниками и алевролитами. Объектом основного внимание на данной площади также являются отложения ПТ.

Поскольку, механизм формирования и геологическое строение остальных локальных поднятий и приуроченных к ним месторождений Бакинского архипелага схожи, то описанные результаты исследований можно отнести и к месторождениям Хамамдаг, Умид, Санги-Мугань, Гиль адасы и другим северным площадям архипелага. В пределах последнего, отложения ПТ состоят, в основном, из чередования песчаников, алевролитов и глин. На одних площадях наблюдается преобладание песчаной фракции над алевритовой, а на других - глинистой относительно алевритовой [1]. 


\section{2. Петрофизическая характеристика коллекторов}

Коллекторские свойства пород в разрезе ПТ детально изучались многими исследователями и, в результате лабораторных исследований, были установлены фракционный состав, фильтрационно-емкостные свойства (ФЕС) пород-коллекторов.

Выявление взаимосвязи между литолого-минералогическом составом и физическими свойствами пород-коллекторов ПТ является основным вопросом требующий решение. Исследования показали, что породы-коллекторы ПТ изменяются от чистых песков до хлидолитов. Изучая детальную характеристику продуктивных горизонтов ПТ месторождения Бакинского архипелага, полученные результаты можно отнести и к соседним структурам.

Исследования дают возможность подтверждать, что на месторождениях Бакинского архипелага кварцевые песчаники преобладают (55\%) над полимиктовыми (45\%). Здесь содержание мономинеральных кварцевых песков составляет 9,5\%, олигомиктовых - 18,1 \%, а мезомиктовых - 17,4\%. Полимиктовые пески, в основном, представлены граувакками - 50,9\% и лититами - 4,1\%. Аркозовые пески в геологическом разрезе архипелага отсутствуют $[4,5]$.

В составе коллекторов Бакинского архипелага содержание основных породообразующих минералов почти равны. Среднее значение кварца составляет 29,1\%, полевого шпата $-22,4 \%$, а обломки минералов $-37,5 \%$.

Содержание кварца в песках составляет $34,2 \%$, а в алевритах - 32\%. Содержание полевого шпата в песчаных породах составляет $44,8 \%$, минеральных обломков $-21 \%$, а в алевролитовых породах содержание полевого шпата соответственно составляет 27,5\%, минеральных обломков - 40,5\%. Таким образом, по минералогическому составу песчаники и алевролиты примерно в два раза отличаются друг от друга и подобны грауваккам.

В литолого-минералогическом отношении породы ПТ северной части Бакинского архипелага, в основном, представлены отложениями апшеронского типа и, частично отложениями кобустанского происхождения. Для отложений характерны высокие значения содержания глинистой фракции $(<0,01$ мм) и песка $(>0,1$ мм) (в среднем каждый составляет 19-30\%). Большую часть отложений занимают алевритовые фракции (40-62\%), с содержанием карбонатного цемента до 12\%. Породы-коллекторы Бакинского архипелага, в основном, отличаются крупно-средне диаметровыми зернами. Так средние значения диаметра зерен соответствуют 161 мкм, при коэффициенте вариации 56\%. Высокое значение коэффициента вариации указывает на низкую отсортированность пород, а медианные размеры зерен в среднем составляют 0,03 мм.

Породы плохо отсортированы, с коэффициентом средней отсортированности не более 3 (коэффициент асимметрии ближе к нулю). В целом породы-коллекторы Бакинского архипелага характеризуются несколько меньшими значениями среднего диаметра (62 мкм), с коэффициентом вариации $50,9 \%$.

Исследования физических свойств вмещающих пород в разрезе месторождений Бакинского архипелага показало, что плотность глинистых пород месторождения Сангачалдениз и Дуваны-дениз составляет 2,26-2,50 г/ $\mathrm{cm}^{3}$, пористость 9,5-18 \% (в некоторых случаях достигает до 30\%), распространение ультразвуковых волн 2200-2300 м/сек. Плотность

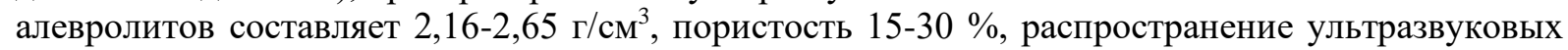

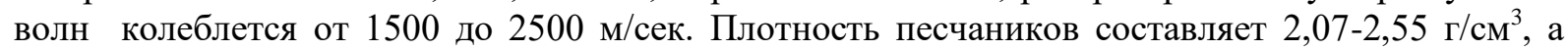
пористость 8,2-22,5\%. Во всех породах распространение ультразвуковых волн, в зависимости от литологического состава, в песчанистых породах изменяется в пределах 950-4000 м/сек. Карбонатные глины ПТ, участвующие в геологическом разрезе площади подвергались изменению и их физические свойства характеризуются следующими величинами: плотность-

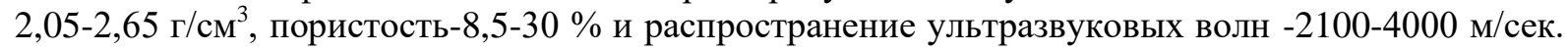
Следует отметить, что карбонатность и проницаемость отложений ПТ в целом также подверглась значительному изменению[6].

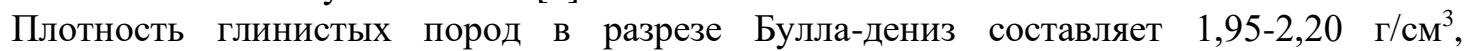
пористость-7,5-25,5 \%, а распространение ультразвуковых волн колеблется между 1950-2300

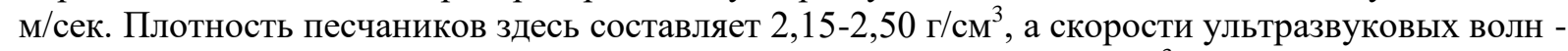

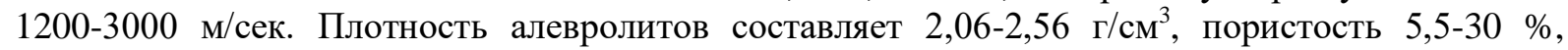
распространение ультразвуковых волн колеблется между 1950-2800 м/сек. 
Таким образом проведенные исследования дают возможность предположить, что изменения физических характеристик исследуемых объектов связаны с литологической неоднородностью основного комплекса, разнообразием пород и тектоническими условиями. Очевидно, что имеется определенная закономерность между гранулометрическим составом, карбонатностью, коэффициентами пористости и проницаемости, для выявления которой были составлены диаграммы и таблица 1, отражающая петрофизические характеристики пород и закономерности изменения петрофизических параметров по площади и по глубине. Определение и вычисление средних значений коллекторских свойств пластов позволяет установить наличие зависимости коллекторских свойств пород между собой и глубиной залегания (Рис. 6).

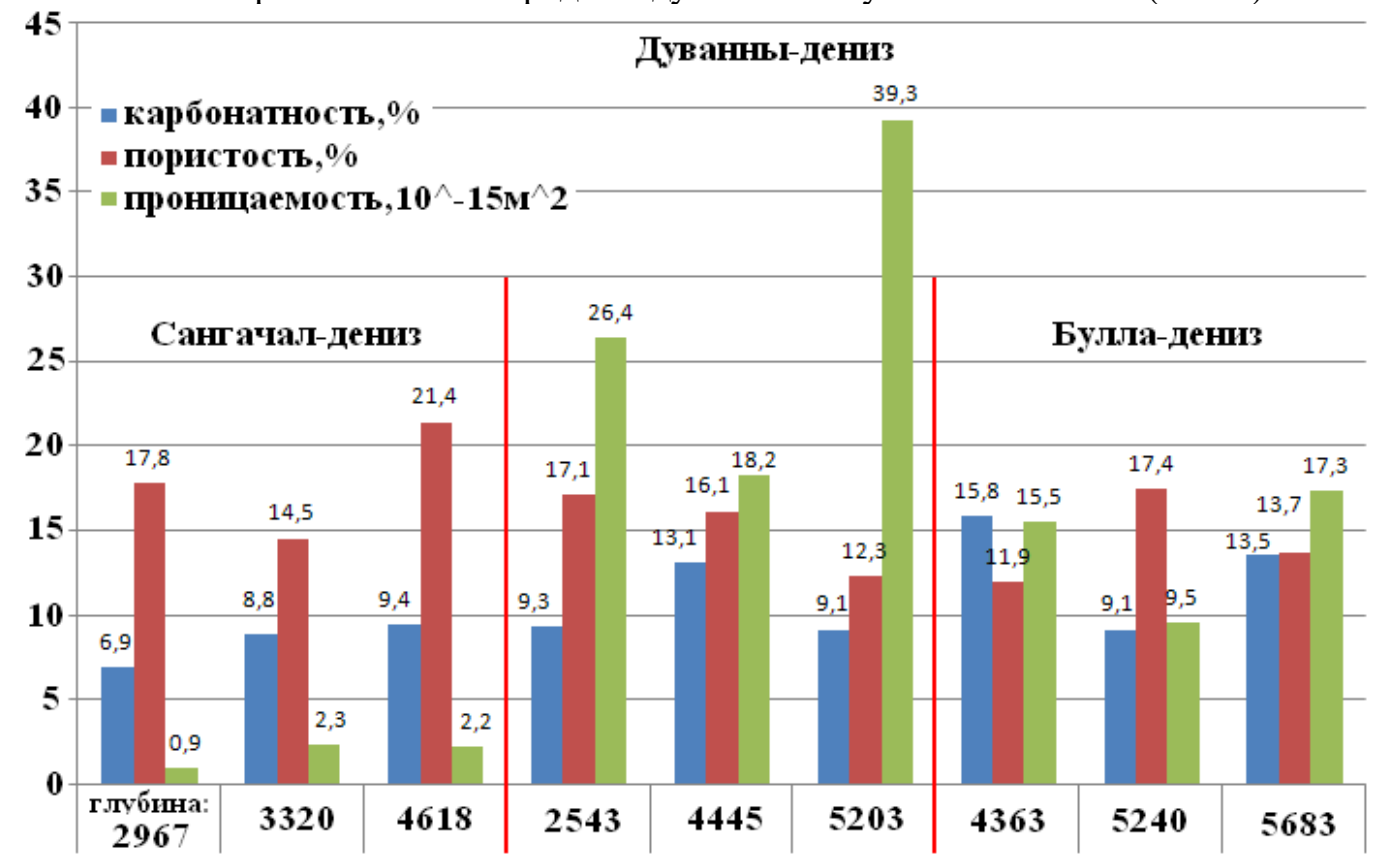

Рис. 6. Диаграммы изменения по глубине коллекторских свойств отложений ПТ в разрезе северной части Бакинского архипелага

Таблица 1. Средние значения и изменение коллекторских свойств отложений ПТ северной части Бакинского архипелага

\begin{tabular}{|c|c|c|c|c|}
\hline \multirow{2}{*}{ интервал } & \multicolumn{5}{|c|}{$\begin{array}{c}\text { Гранулометрический состав, \% } \\
\text { (фракции, мм) }\end{array}$} \\
\cline { 2 - 5 } & $>0,25$ & $0,25-0,1$ & $0,1-0,01$ & $<0,01$ \\
\hline 2967 & 2,0 & 35,5 & 38,2 & 25,7 \\
\hline 3320 & 0,6 & 20,8 & 50,1 & 28,8 \\
\hline 4618 & 3,23 & 43,07 & 37,3 & 16,6 \\
\hline \multicolumn{5}{|c|}{ Сангачалы -дениз } \\
\hline 2543 & 3,18 & 20,94 & 50,92 & 24,83 \\
\hline 4445 & 15,63 & 50,5 & 23,27 & 13,07 \\
\hline 5203 & 1,4 & 20,76 & 45,8 & 32,32 \\
\hline 4363 & 0,46 & 7,31 & 54,62 & 37,78 \\
\hline 5240 & 2,7 & 58,7 & 15,45 & 23,15 \\
\hline 5683 & - & 42,55 & 40,2 & 17,25 \\
\hline
\end{tabular}

Эти данные, полученные в результате исследований, позволяют сделать следующие выводы. До глубины 4580 м в гранулометрическом составе пород в целом происходит существенное нарастание псаммитовой фации с одновременным убыванием алевритовой и пелитовой фракций с незначительными колебаниями значений карбонатности. В результате, на 
фоне незначительного увеличения пористости происходит относительно резкое возрастание проницаемости (до 122,0 - 185,5 х $10^{-15} \mathrm{~m}^{2}$ ), что, вероятно, связано с вышеотмеченным изменением гранулометрического состава пород. При этом в интервале глубин 2564-3401 м породы характеризуются низкими значениями содержания псаммитовой и повышенным содержанием алеврито-пелитовой фракции. Очевидно, такой фракционный состав и является причиной почти полного отсутствия в них проницаемости $\left(0,9-2,3 \times 10^{-15} \mathrm{~m}^{2}\right)$.

Далее в интервале глубин 3401- 4580 м наблюдается резкое возрастание псаммитовой фракции до $66,2 \%$ и уменьшение алеврито-пелитовой, что привело к относительно резкому

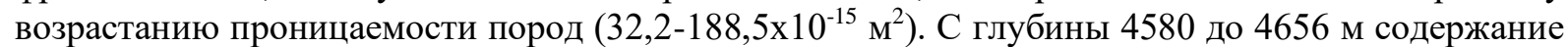
псаммитовой фракции в породах уменьшается до $47,3 \%$ с одновременным нарастанием алеврито-пелитовой фракции и карбонатности. Такое изменение фракционного состава приводит к резкому падению проницаемости до $2,23 \times 10^{-15} \mathrm{~m}^{2}$, что можно считать закономерным для гранулярных резервуаров.

В интервале глубин 4656-5109 м вновь происходит возрастание псаммитовой фации до $61,4 \%$ с относительно резким падением содержания алевритов до $15,43 \%$ и с незначительным возрастанием пелитовой фракции (до 15,43\%). Такое сочетание отмеченных фракций привело к

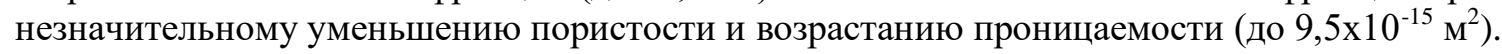

В следующем интервале глубин (5175-5232 м) происходит резкое уменьшение содержания псаммитов до $22,16 \%$, трехкратное возрастание алевритовой и увеличение пелитовой фракции (почти на 10\%) при относительно низкой карбонатности. Все это привело к возрастанию проницаемости до $59,33 \times 10^{-15} \mathrm{~m}^{2}$.

Далее, в интервале глубин 5660-5702 м в очередной раз псаммитовая фракция возрастает до $42,65 \%$, т.е. алевриты уменьшаются до $40,0 \%$ и почти в два раза убывает пелитовая фракция (составляя всего 17,35\%). При этом незначительно возрастает карбонатность, в результате при пористости 13,65 \% проницаемость пород возростает до 173,0х10-15 ${ }^{2}$.

Изложенный выше анализ позволяет заключить, что пористость и, в особенности, проницаемость гранулярных коллекторов в разрезе исследуемой территории контролируется главным образом количественным содержанием псаммито-алевритовой и, в особенности, псаммитовой, фракцией. Такая зависимость свойств пород-коллекторов свидетельствует о незначительном развитии или полном отсутствии в них вторичной пористости, связанной в основном с трещиноватостью, кавернозностью и т. д. В свою очередь низкая карбонатность исключает вероятность процесса выщелачивания, который способствует возрастанию коллекторских характеристик преимущественно у карбонатных пород. Об отсутствии этого процесса в рассматриваемых породах свидетельствует не только их низкая карбонатность, но также их низкие коллекторские свойства [7-10].

Учитывая прямую зависимостью между плотностью пород и скоростью прохождения ультразвуковых волн, они хорошо коррелируются между собой (Рис. 6). Однако, между литофациальными, коллекторскими и отмеченными физическими параметрами пород в нашем случае более или менее ясно выраженной зависимости не наблюдалось.

\section{Выводы.}

- в пределах исследованных морских месторождений изменение петрографических свойств в широком диапазоне значений связано, в основном, с литологической неоднородностью, глубиной и структурно-тектоническими условиями залегания пластов.

- хорошая корреляционная связь, между пористостью и проницаемостью связана с терригенным составам, литофациальной идентичностью и близостью значений пористости пород-коллекторов, а относительно высокие значения проницаемости связаны с повышенным содержанием псаммит-алевритовых фракций.

- при прогнозировании нефтегазоносности глубокопогруженных структур, наряду с оптимальными геофизическими методами разведки необходимо учитывать и фильтрационноемкостные характеристики пород.

- изменение плотности пород и скорости ультразвуковых волн с глубиной указывают на их хорошую коррелируемость, а отсутствие таковой между ними и коллекторскими свойствами пород свидетельствует, в основном, об отсутствии в породах-коллекторах вторичной пористости. 


\section{ЛИТЕРАТУРА}

1. Али-заде А.А., Ахмедов Г.А., Ахмедов А.М., Алиев А.К., Зейналов М.М. - Геология нефтяных и газовых месторождений Азербайджана. // Изд.: Недра, 1966. - 390 с.

2. Физические свойства горных пород и полезных ископаемых. Под ред. Н.Б.Дортман, М.:Недра, 1976, стр. 527.

3. Сулейманов Ш.А., Мирзоев И.А., Мехтиев И.П. «Коллекторские свойства отложений ПТ разрабатываемых месторождениях северной части Бакинского архипелага»- АНХ, 2005, № 1, с. 2-16.

4. “Составление каталога коллекторских свойств мезокайнозойских отложений месторождений нефтигаза и перспективных структур Азербайджана" - отчет Научно-Исследовательского Института Геофизики - 105-2009. Фонды Управления Геофизики и Геологии. Баку - 2010.

5. Гурбанов В.Ш., Султанов Л.А., Валиев С.А., Бабаева М.Т. Литолого-петрографические и коллекторские характеристики мезокайнозойских отложений северо-западной части Южно-Каспийской впадины // Вестник Пермского национального исследовательского политехнического университета. Геология. Нефтегазовое и горное дело. - 2015. - № 17. - С. 5-15. DOI: 10.15593/2224-9923/2015.17.1

6. Кожевников Д.А. Петрофизическая инвариантность гранулярных коллекторов. // Геофизика.- 2001 № 4. 31-37 c.

7. Нариманов Н.Р., Мухтарова Х.З., Насибова Г.Д. «Геологическое развитие и нефтегазоносность локальных поднятий Бакинского архипелага Южно-Каспийского бассейна», Известия Томского политехнического университета. Инжиниринг георесурсов. 2019. Т. 330. o 6. 164-173; http://izvestiya.tpu.ru/archive/issue/view/97; https://www.scopus.com/sourceid/21100812103?origin=resultslist;

8. Юсифов Х., Асланов Б. «Нефтегазоносные бассейна Азербайджана», Баку, 2018, 323 стр.;

9. Мехтиев Ш.Ф. «Избранные труды», Баку 2010, 474 стр.;

10. Алиев А.Г. «Избранные труды», Баку, 2011, 527 стр. 